\title{
Soil carbon sequestration by three perennial legume pastures is greater in deeper soil layers than in the surface soil
}

\author{
X.-K. Guan ${ }^{1}$, N. C. Turner ${ }^{2,3}$, L. Song ${ }^{4}$, Y.-J. Gu' ${ }^{2}$, T.-C. Wang ${ }^{1}$, and F.-M. Li ${ }^{2,3}$ \\ ${ }^{1}$ Collaborative Innovation Center of Henan Grain Crops, Agronomy College of Henan Agricultural University, \\ Zhengzhou, Henan 450002, China \\ ${ }^{2}$ State Key Laboratory of Grassland Agro-Ecosystem, Institute of Arid Agroecology, School of Life Sciences, \\ Lanzhou University, Lanzhou 730000, China \\ ${ }^{3}$ The UWA Institute of Agriculture and Centre for Plant Genetics and Breeding, The University of Western \\ Australia, M080, Perth, WA 6009, Australia \\ ${ }^{4}$ Medical College of Northwest University for Nationalities, Lanzhou 730030, China \\ Correspondence to: T.-C. Wang (wtcwrn@126.com) and F.-M. Li (fmli@1zu.edu.cn)
}

Received: 22 April 2015 - Published in Biogeosciences Discuss.: 8 July 2015

Revised: 18 December 2015 - Accepted: 4 January 2016 - Published: 28 January 2016

\begin{abstract}
Soil organic carbon (SOC) plays a vital role as both a sink for and source of atmospheric carbon. Revegetation of degraded arable land in China is expected to increase soil carbon sequestration, but the role of perennial legumes on soil carbon stocks in semiarid areas has not been quantified. In this study, we assessed the effect of alfalfa (Medicago sativa L.) and two locally adapted forage legumes, bush clover (Lespedeza davurica S.) and milk vetch (Astragalus adsurgens Pall.) on the SOC concentration and SOC stock accumulated annually over a $2 \mathrm{~m}$ soil profile. The results showed that the concentration of SOC in the bare soil decreased slightly over the 7 years, while 7 years of legume growth substantially increased the concentration of SOC over the $0-2.0 \mathrm{~m}$ soil depth. Over the 7-year growth period the SOC stocks increased by $24.1,19.9$ and $14.6 \mathrm{Mg} \mathrm{C} \mathrm{ha}^{-1}$ under the alfalfa, bush clover and milk vetch stands, respectively, and decreased by $4.2 \mathrm{MgC} \mathrm{ha}^{-1}$ in the bare soil. The sequestration of SOC in the 1-2 m depth of the soil accounted for 79,68 and $74 \%$ of the SOC sequestered in the $2 \mathrm{~m}$ deep soil profile under alfalfa, bush clover and milk vetch, respectively. Conversion of arable land to perennial legume pasture resulted in a significant increase in SOC, particularly at soil depths below $1 \mathrm{~m}$.
\end{abstract}

\section{Introduction}

Concerns about global warming and increasing atmospheric greenhouse gas concentrations $\left(\mathrm{CO}_{2}, \mathrm{CH}_{4}\right.$, and $\left.\mathrm{N}_{2} \mathrm{O}\right)$ have led to questions on the role of soils as a source or sink for carbon. Excluding carbonated rocks, soils constitute the largest surface carbon pool, approximately $1500 \mathrm{Gt}$, equivalent to almost twice that in the terrestrial biomass and three times that in the atmosphere (IPCC, 2000). Globally, soil cultivation has resulted in the loss of more than $40 \mathrm{PgC}$, at a rate of about $1.6 \mathrm{PgC} \mathrm{yr}^{-1}$, to the atmosphere during the $1990 \mathrm{~s}$ (Smith, 2008). Chinese agricultural soils have also lost 30 $50 \%$ or more of the soil carbon pool (Lal, 2004a).

Soil organic carbon (SOC) is a significant component of the global carbon stocks (Chen et al., 2008). Globally, $24 \%$ of the SOC stock has been lost through the conversion of forest to cropland (He et al., 2011) and 59\% through the conversion of pasture to cropland (Zhu, 1994). Fortunately, the loss of SOC can be slowed down by implementing crop management practices such as conservation tillage (Lal, 2004b; Puget and Lal, 2005), converting degraded arable land to perennial grassland (Gentile et al., 2005), using diverse rotations, and introducing legume and grass mixtures into the rotation (Lal, 2002, 2004b, c).

In the USA, the revegetation of highly-erodible cropland or other environmentally sensitive areas to resourceconserving vegetation for a period of 10 to 15 years increased 
the SOC content in the upper $3 \mathrm{~m}$ of soil at an average rate of $1.1 \mathrm{Mg} \mathrm{Cha}^{-1} \mathrm{yr}^{-1}$ (Osborn, 1993). This conservation reserve program (CRP) also significantly increased the soil C pool (Staben et al., 1997) and provided multiple benefits both environmentally and economically (Munson et al., 2012; Wu and Lin, 2010). Like the CRP program in the USA, a program of soil and water conservation, namely "Grain for Green" was implemented on the Loess Plateau of China in 1999 to alleviate land degradation. The program of ecoenvironmental revegetation focused on the recovery of damaged ecosystems (Wang et al., 2010) by the use of perennial vegetation to control soil erosion, increase the stocks of SOC and prevent the occurrence of dry layers in the loess soils (Fu et al., 2010). Alfalfa (Medicago sativa L.) has been widely grown on the Loess Plateau to increase livestock production and improve water-use efficiency and soil fertility through high forage production, and for its ability to decrease soil erosion and fix atmospheric N (Guan et al., 2013). Additionally, locally adapted legume species such as bush clover (Lespedeza davurica S.) and milk vetch (Astragalus adsurgens Pall.) have been widely grown as cover crops or windbreaks to protect the soil from water and wind erosion in arid and semiarid regions of northern China (Wang, 2003; Xu et al., 2006). The "Grain for Green" program has reduced wind and water erosion of marginal arable land and is expected to significantly contribute to soil $\mathrm{C}$ sequestration. Recent studies on the Loess Plateau have investigated and estimated the changes in SOC stocks in the top $1 \mathrm{~m}$ of soil as a result of revegetation of regional watersheds (Fu et al., 2010; Wang et al., 2011; Yan et al., 2007; Zhang et al., 2013). However, deep-rooted perennial legumes may penetrate deeper in the soil profile than $1 \mathrm{~m}$, likely underestimating the SOCsequestration potential of these forage legumes in northwest China (Smith et al., 2015).

The objective of this research was to assess the effect of alfalfa and two locally adapted forage legumes, bush clover and milk vetch, on the SOC concentration and SOC stock accumulated annually for 7 years over a $2 \mathrm{~m}$ soil profile. The SOC content in the $2 \mathrm{~m}$ soil profile was measured at the end of each growing season to quantify the SOC concentration and stock under the locally adapted forage legumes and alfalfa, and to provide specific information for estimating the SOC sequestration potential of an important agricultural area. The hypothesis tested was that long-term growth of deep-rooted perennial legumes will increase soil organic $\mathrm{C}$, provide a feed source for animals and provide a sink for atmospheric carbon.

\section{Materials and methods}

\subsection{Experimental site description}

The experiment was conducted at the Changwu Agroecological Experiment Station on the Loess Plateau

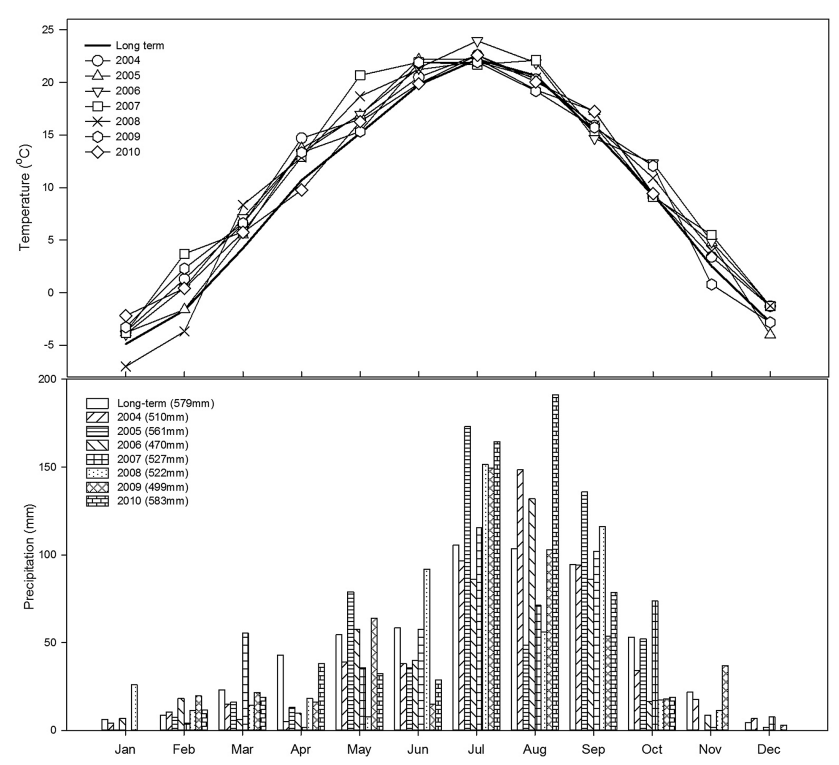

Figure 1. Mean monthly temperature and precipitation from 20042010 and the long-term mean at the experimental site at Changwu Agricultural Research Station, Shaanxi Province, China.

$\left(35^{\circ} 12^{\prime} \mathrm{N}, 107^{\circ} 40^{\prime} \mathrm{E}\right)$, Shaanxi province, China, from 2004 to 2010 . The level site is located at $1220 \mathrm{~m}$ above sea level. The climate is semiarid, with an annual mean temperature of $9.1^{\circ} \mathrm{C}$ and a mean annual precipitation of $579 \mathrm{~mm}$ (19792003) with rainfall concentrated in the period from July to September. Precipitation and temperature data were recorded at the Changwu Meteorological Station, $20 \mathrm{~m}$ from the experimental site. The groundwater table is $50-80 \mathrm{~m}$ below the soil surface, making it unavailable for plant growth. Prior to the establishment of this experiment, the site was planted to winter wheat for many (at least 20) years. For winter wheat production, the site was ploughed to a depth of $0.3 \mathrm{~m}$ twice a year, after harvest in early July and again in September before sowing; only wheat stubble was returned to the soil, but $108 \mathrm{~kg} \mathrm{~N} \mathrm{ha}^{-1}$ and $276 \mathrm{~kg} \mathrm{P}_{2} \mathrm{O}_{5} \mathrm{ha}^{-1}$ of fertilizer was applied each year before sowing. In 2003, after the winter wheat was harvested, the site remained fallow for 280 days to allow moisture accumulation over the winter before the legumes were sown in May 2004.

Soil at the experimental site belongs to the Loess series. The texture in the top $5 \mathrm{~m}$ is a uniform silty clay loam (haplic greyxems, FAO-UNESCO, 1988), with a mean sand, silt, and clay content of $3.5,65.6$, and $30.9 \%$, respectively. The soil physical characteristics do not significantly change in the upper $5 \mathrm{~m}$. The measured average bulk density of the soil in the upper $2 \mathrm{~m}$ is $1.31 \mathrm{~g} \mathrm{~cm}^{-3}$, does not change with depth, and the top $0.3 \mathrm{~m}$ contained $1.55 \%$ total organic matter, $0.106 \%$ nitrogen, and $0.095 \%$ available phosphate prior to the commencement of the experiment in 2004. 


\subsection{Treatments and measurement of aboveground biomass}

Twelve experiment plots, each $4 \mathrm{~m}$ by $3 \mathrm{~m}$, were established in early May 2004 with one of three forage legume species, milk vetch (Astragalus adsurgens Pall.), alfalfa (Medicago sativa $\mathrm{L}$.) and bush clover (Lespedeza davurica S.), and an unplanted control. Each legume species was grown as an evenly spaced monoculture (but assumed a more patchy distribution with time) at a seeding density of 25 plants $\mathrm{m}^{-2}$, weeds were removed from all plots by hand. The plots were adjacent to each other. During the experimental period from 2004 to 2010, there was no irrigation or other form of supplementary water and the plots were not fertilized. The plants were not inoculated, but relied on the naturally occurring root nodule bacteria from previous growth of the three species on the experimental station. Lack of nodulation was not observed to be a problem. Treatments were completely randomized in three replicate blocks.

Each year from 2005-2010, measurements of aboveground biomass production for each legume were taken at the end May, July and September (in 2004 only one cut was made in September) by cutting the plants at ground level with hand-held shears in a randomly-selected $1 \mathrm{~m} \times 1 \mathrm{~m}$ quadrat within each plot, but avoiding border areas. At the same time, the rest of the plot was also cut at the same height and the forage removed. The oven-dry weight was determined after drying at $105^{\circ} \mathrm{C}$ for $0.5 \mathrm{~h}$ and then further dried at $75^{\circ} \mathrm{C}$ for $48 \mathrm{~h}$ (Guan et al., 2013).

\subsection{Soil sampling and analysis}

Soil samples were taken with a cylindrical steel corer (diameter $40 \mathrm{~mm}$ and height $200 \mathrm{~mm}$ ) at two random positions in each plot which were combined into one composite sample per plot before analysis. Each plot was sampled from the surface to $2 \mathrm{~m}$ deep at depths of $0-0.3,0.3-0.6,0.6-1.0,1.0$ 1.5 and $1.5-2.0 \mathrm{~m}$ before sowing on 10 May 2004 and at the end of each growing season (29 October) from 2004 to 2010. The soil samples were air-dried, roots and organic debris removed, ground and sieved through a $2 \mathrm{~mm}$ sieve, then stored at room temperature before analyzing the SOC.

The concentration of SOC (in $\mathrm{g} \mathrm{kg}^{-1}$ ) was measured using the wet dichromate oxidation procedure (Moinuddin and Khanna-Chopra, 2004). Briefly, a $0.5 \mathrm{~g}$ soil sample was digested with $5 \mathrm{~mL}$ of $1 \mathrm{~N} \mathrm{~K}_{2} \mathrm{Cr}_{2} \mathrm{O}_{7}$ and $5 \mathrm{~mL}$ of concentrated $\mathrm{H}_{2} \mathrm{SO}_{4}$ at $150^{\circ} \mathrm{C}$ for $0.5 \mathrm{~h}$, followed by titration of the digest with standardized $\mathrm{FeSO}_{4}$.

\subsection{SOC stock calculation and statistical analyses}

Soil organic C stock was calculated as Eq. (1):

$\mathrm{C}_{\text {stock }}=\mathrm{SOC} \times \rho \times H \times 10$,
Table 1. Annual aboveground biomass production of the three legume species, milk vetch, alfalfa and bush clover, from 2004 to 2010. Adopted from Guan et al. (2013) and used with permission.

\begin{tabular}{lrrr}
\hline \multirow{2}{*}{ Year } & \multicolumn{3}{c}{ Aboveground biomass production } \\
& \multicolumn{3}{c}{$\left(\mathrm{t} \mathrm{ha}^{-1}\right)$} \\
\cline { 2 - 4 } & Milk vetch & Alfalfa & Bush clover \\
\hline 2004 & $2.2 \mathrm{Ac}$ & $2.3 \mathrm{Ad}$ & $0.2 \mathrm{Bd}$ \\
2005 & $14.1 \mathrm{Ba}$ & $20.2 \mathrm{Aa}$ & $5.3 \mathrm{Cc}$ \\
2006 & $14.3 \mathrm{Ba}$ & $22.2 \mathrm{Aa}$ & $7.8 \mathrm{Ca}$ \\
2007 & $6.8 \mathrm{Bb}$ & $9.3 \mathrm{Ac}$ & $6.4 \mathrm{Bbc}$ \\
2008 & $5.6 \mathrm{Bb}$ & $13.4 \mathrm{Ab}$ & $7.3 \mathrm{Bab}$ \\
2009 & $7.2 \mathrm{Bb}$ & $12.4 \mathrm{Ab}$ & $7.8 \mathrm{Ba}$ \\
2010 & $5.8 \mathrm{Bb}$ & $10.8 \mathrm{Abc}$ & $7.4 \mathrm{Bab}$ \\
$2004-2010$ Mean & $8.0 \mathrm{~B}$ & $13.0 \mathrm{~A}$ & $6.0 \mathrm{C}$ \\
$2004-2010$ Total & $56.0 \mathrm{~B}$ & $90.7 \mathrm{~A}$ & $42.1 \mathrm{C}$ \\
\hline
\end{tabular}

Data in each column with a different lower-case letter are significantly different $(P<0.05)$ and data in each row with a different capital letter are significantly different $(P<0.05)$.

where SOC is the SOC concentration $\left(\mathrm{g} \mathrm{kg}^{-1}\right)$ in each soil layer, $\rho$ is the bulk density $\left(\mathrm{g} \mathrm{cm}^{-3}\right)$ of the soil, and $H$ is the depth of each layer.

The data were analyzed by analysis of variance (ANOVA), and means were compared using the LSD at $P<0.05$ to characterize the differences among treatments. PROC GLM (General Linear Model) in the Statistical Analysis System (SAS Institute, Cary, NC, version 8.02) software was used to assess the temporal changes in SOC stock and the rate and amount of SOC sequestered.

\section{Results}

\subsection{Meteorological conditions}

The average monthly mean temperature from June to August, the primary growth period for the legumes, was about $20^{\circ} \mathrm{C}$. Monthly mean temperatures were about $1{ }^{\circ} \mathrm{C}$ warmer than the long-term mean throughout the experimental period (Fig. 1). Over the experimental period, the total annual precipitation varied from $470 \mathrm{~mm}$ in 2006 to $583 \mathrm{~mm}$ in 2010, and was below the long-term mean in all years except 2010 when the rainfall was similar to the long-term mean (Fig. 1). Rainfall from July to September accounted for $55-60 \%$ of total annual precipitation, while rainfall in the legume-growing season (from April to October) was about $90 \%$ (range from $84 \%$ in 2009 to $96 \%$ in 2005) of the total annual precipitation (Fig. 1).

\subsection{Aboveground forage biomass production}

The results of the aboveground biomass production over the 7 years have been reported by Guan et al. (2013). Briefly, the annual production of milk vetch increased from $2.2 \mathrm{tha}^{-1}$ in 
Table 2. Results of the ANOVA for soil organic carbon concentration as affected by legume species, soil depth and experimental year. The bare soil plot is considered as a legume species in the analysis. The SAS PROC ANOVA was used in the analysis.

\begin{tabular}{lrrr}
\hline Factors & $\mathrm{d} f$ & $F$ value & $\operatorname{Pr}>F$ \\
\hline Species & 3 & 38.52 & 0.0003 \\
Depth & 4 & 1649.40 & $<0.0001$ \\
Year & 7 & 31.68 & $<0.0001$ \\
Species · Depth & 12 & 5.65 & $<0.0001$ \\
Species · Year & 21 & 5.96 & $<0.0001$ \\
Depth - Year & 28 & 3.20 & $<0.0001$ \\
Species · Depth · Year & 84 & 0.95 & 0.6053 \\
\hline
\end{tabular}

the first year to $14.3 \mathrm{tha}^{-1}$ in 2006 and then decreased, alfalfa increased from $2.3 \mathrm{tha}^{-1}$ in the first year to a maximum of $22.2 \mathrm{tha}^{-1}$ in 2006 and then decreased, while bush clover increased from $0.2 \mathrm{tha}^{-1}$ in the first year to $7.8 \mathrm{tha}^{-1}$ in 2009 and did not decrease significantly thereafter (Table 1). Total aboveground biomass production over the experimental period was highest in alfalfa at $91 \mathrm{tha}^{-1}$ (equivalent to $43 \mathrm{MgC} \mathrm{ha}^{-1}$ assuming a $\mathrm{C}$ to dry weight ratio of 0.475 , Magnussen and Reed, 2004) compared to $56 \mathrm{tha}^{-1}$ $\left(27 \mathrm{MgC} \mathrm{ha}^{-1}\right)$ in milk vetch and $42 \mathrm{tha}^{-1}\left(20 \mathrm{Mg} \mathrm{Cha}^{-1}\right)$ in bush clover (Table 1).

\subsection{SOC concentration over the soil profile}

The legumes significantly $(P<0.001)$ increased the SOC concentration at each soil depth, and this effect varied with legume species and experimental year (Table 2). The initial concentration of SOC in May 2004 decreased with increasing soil depth (Fig. 2). In the upper $0-0.3 \mathrm{~m}$ of soil, the initial SOC concentration was $8.0 \pm 0.03 \mathrm{~g} \mathrm{~kg}^{-1}$, while it was only $3.3 \pm 0.27 \mathrm{~g} \mathrm{~kg}^{-1}$ in the $1.5-2.0 \mathrm{~m}$ soil layer (Fig. 2). Comparison of the SOC concentration between the initial values on 10 May 2004 and those at the end of the experimental period in October 2010 showed that the concentration of SOC in the bare soil decreased slightly over the 7 years, while 7 years of legume growth substantially increased the concentration of SOC over whole $2 \mathrm{~m}$ soil depth. There were large increases in the concentration of SOC at 0.6-1.0, 1.0-1.5 and 1.5-2.0 $\mathrm{m}$ soil depth and a small, but significant, increase in the upper $0.3 \mathrm{~m}$ of the soil in bush clover, but not in milk vetch and alfalfa. No significant changes were observed after 7 years at the $0.3-0.6 \mathrm{~m}$ depth (Fig. 2).

\subsection{SOC stock over the experimental period}

SOC stock was calculated by converting SOC concentration to the amount of SOC per soil layer per unit area. The SOC stock in 2004 varied from $21.4 \pm 0.85 \mathrm{Mg} \mathrm{Cha}^{-1}$ in the $0.3-0.6 \mathrm{~m}$ soil layer to $32 \pm 0.14 \mathrm{MgCha}^{-1}$ and $32 \pm 0.68 \mathrm{MgCha}^{-1}$ at $0-0.3$ and $1.0-1.5 \mathrm{~m}$ depth respec-

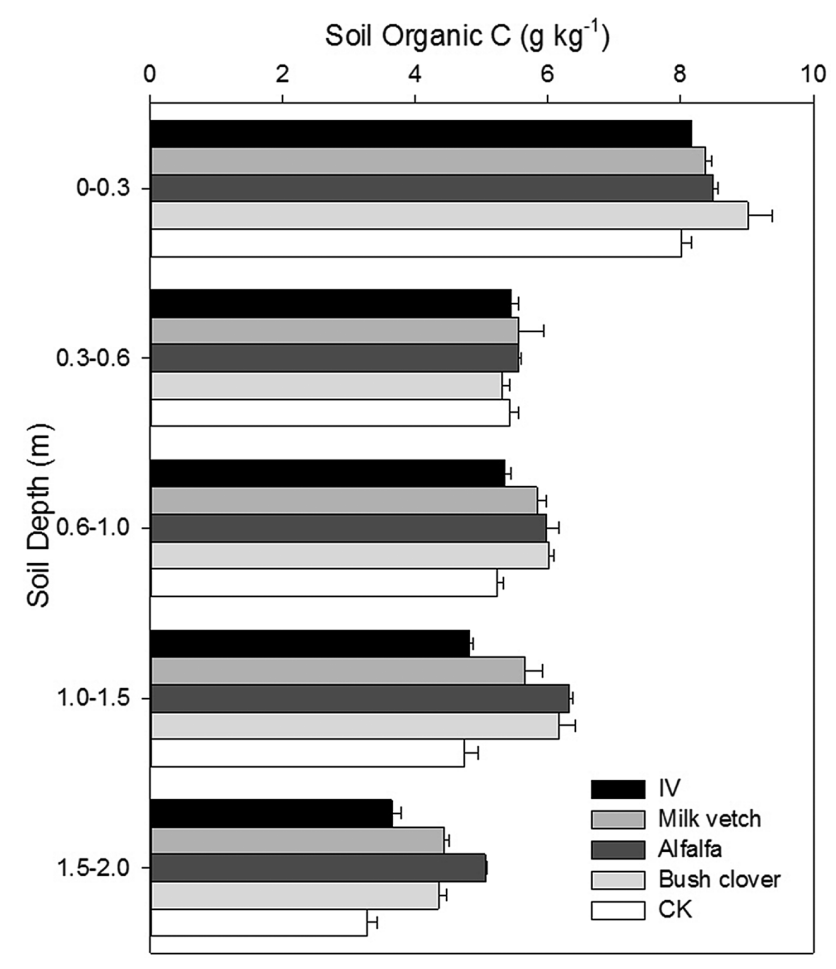

Figure 2. Concentration of soil organic carbon (SOC) with depth in May 2004 (IV) and in October 2010 under three forage legumes: milk vetch, alfalfa and bush clover, and bare soil (CK). Bars give + one standard error of the mean $(n=3)$.

tively (Fig. 3). In the bare soil, the SOC stock decreased at all depths across the experimental period, but only decreased significantly at $-0.36 \mathrm{MgC} \mathrm{ha}^{-1} \mathrm{yr}^{-1}(P<0.05)$ in the 1.5-2.0 $\mathrm{m}$ layer (Fig. 3d), presumably from the decay and turnover of the wheat roots accumulated over the many years of wheat production prior to the planting of the legumes. In the legume plots, the SOC stock increased linearly with time (2004-2010) in the 0-0.3, 0.6-1.0, 1.0-1.5 $\mathrm{m}$ and $1.5-2.0 \mathrm{~m}$ soil layers, but not in the $0.3-0.6 \mathrm{~m}$ soil layer (Fig. 3). The change in SOC stock over the 7 years was greatest at soil depths below $1.0 \mathrm{~m}$ in all three species and was greatest in the alfalfa plots with rates of $1.35 \mathrm{MgC} \mathrm{ha}^{-1} \mathrm{yr}^{-1}$ at a depth of $1.0-1.5 \mathrm{~m}(P<0.001$; Fig. $3 \mathrm{~d})$, and $1.39 \mathrm{Mg} \mathrm{Cha}^{-1} \mathrm{yr}^{-1}$ at a depth of $1.5-2.0 \mathrm{~m}(P<0.001$; Fig. 3e). The highest accumulation of SOC stock occurred at a depth of 1.0-1.5 $\mathrm{m}$ in bush clover where it averaged $1.58 \mathrm{MgCha}^{-1} \mathrm{yr}^{-1}(P<0.001$; Fig. 3d).

Over the full $0-2.0 \mathrm{~m}$ depth, the SOC stock at the beginning of the experiment in 2004 was $137 \mathrm{Mg} \mathrm{Cha}^{-1}$, decreased to $133 \mathrm{Mg} \mathrm{Cha}^{-1}$ in the bare soil plots, while it increased to 151,157 and $161 \mathrm{Mg} \mathrm{Cha}^{-1}$ under the milk vetch, bush clover and alfalfa stands, respectively, by the end of the experiment in 2010 (Fig. 4). The SOC stock increased more under the stand of alfalfa than milk vetch, but there was no significant difference between alfalfa and bush clover 

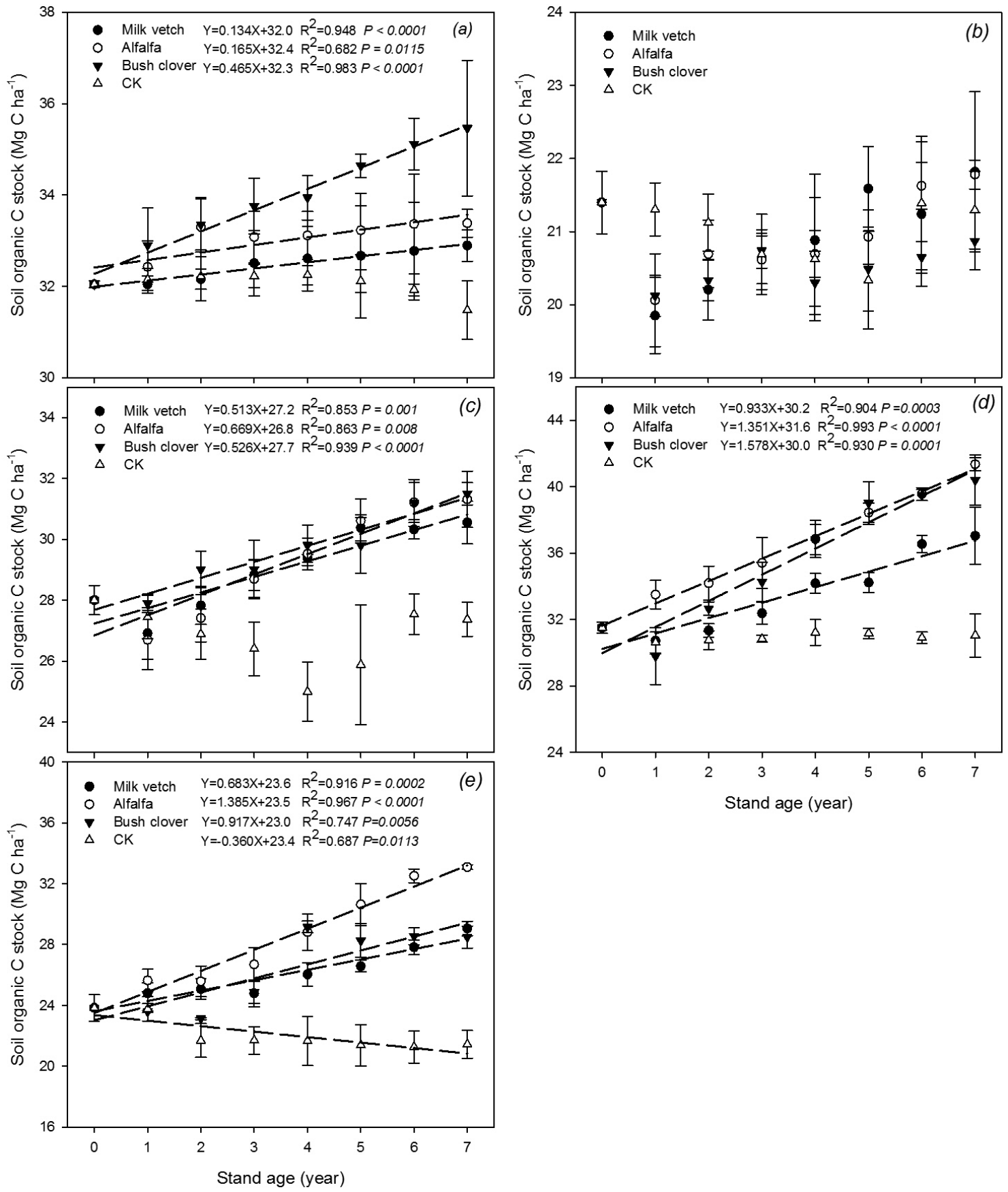

Figure 3. Change with stand age in soil organic carbon amount (stock) per hectare at soil depths of 0-0.3 (a), 0.3-0.6 (b), 0.6-1.0 (c), 1.0-1.5 (d) and 1.5-2.0 m (e) under milk vetch, alfalfa, bush clover and bare soil (CK). Note the soil layers vary in depth. Data are means \pm one standard error of the mean $(n=3)$ when larger than the symbol. Linear regressions fitted when significant and fitted regressions given. 


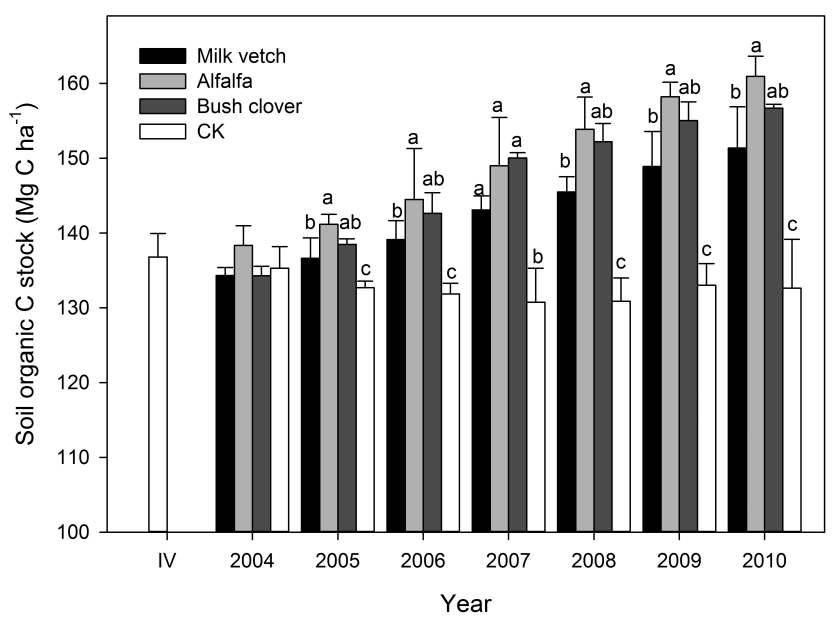

Figure 4. The soil organic carbon amount (stock) under milk vetch, alfalfa, bush clover and under bare soil (CK) over the upper $2 \mathrm{~m}$ of the soil profile. The lower case letters indicate significant differences $(P<0.05)$ between forage types and bare soil $(\mathrm{CK})$ within a year. IV denotes initial value, the soil organic carbon stock in May 2004. Bars give + one standard error of the mean $(n=3)$.

(Fig. 4). When calculated over the full $2 \mathrm{~m}$ soil layer, over the 7-year growth period, the SOC stocks increased by 24.1, 19.9 and $14.6 \mathrm{MgC} \mathrm{ha}^{-1}$ under the alfalfa, bush clover and milk vetch stands, respectively, and decreased by $4.2 \mathrm{MgC} \mathrm{ha}^{-1}$ under bare soil (Fig. 5). In the 1.0-2.0 m soil layer the stocks of SOC increased by $19.1,13.6$ and $10.8 \mathrm{MgCha}^{-1}$, under the alfalfa, bush clover and milk vetch stands, respectively, that is, by 79,68 and $74 \%$ of the increases over the whole soil profile (Fig. 5).

\section{Discussion}

While the unplanted plots lost SOC over the 7 years of the study, particularly over the first 5 years, all three forage legumes more than countered this loss, so that over the 7 years the SOC increased on average by $2.1,2.8$ and $3.4 \mathrm{Mg} \mathrm{Cha}^{-1} \mathrm{yr}^{-1}$, to sequester 15,20 and $24 \mathrm{MgCha}^{-1}$ under the milk vetch, bush clover and alfalfa stands, respectively (Fig. 5). The legumes increased the SOC primarily at depth (Fig. 2) with between 68 and $79 \%$ of the SOC being sequestered below $1 \mathrm{~m}$.

An increase in SOC stock is usually associated with the production, turnover, sloughing off of epidermal cells, and exudation of soluble carbon compounds by the roots, particularly the turnover and exudation by fine roots (Luo et al., 1995). A high rate of turnover of fine roots and a high rate of exudation of carbon by the roots influences the stability of plant C in soil and the accumulation of SOC (Shahzad et al., 2015). Although the root biomass was not measured in this study, root biomass is usually associated with aboveground biomass. If the root: shoot biomass ratio is known, the root

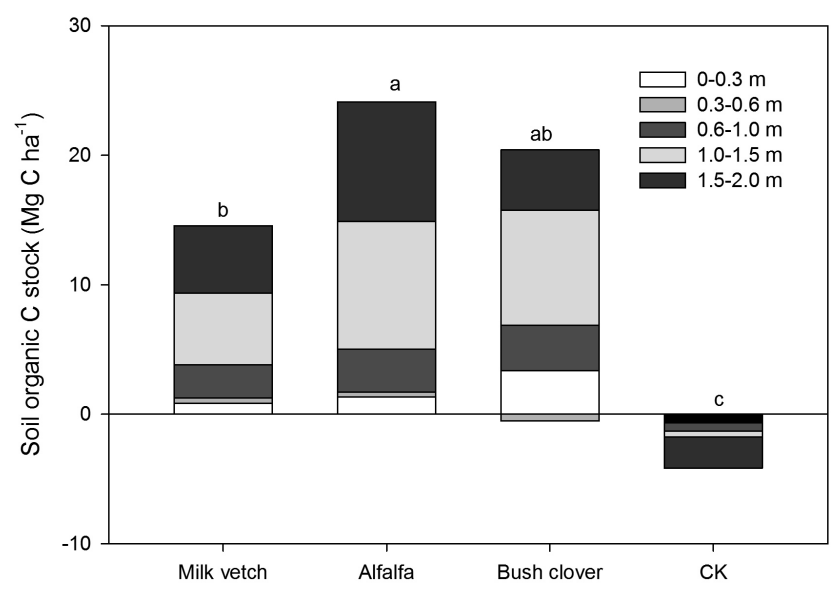

Figure 5. Change in soil organic carbon amount (stock) in different soil layers under milk vetch, alfalfa, bush clover and bare soil (CK) from May 2004 to October 2010. Different letters indicate significant differences $(P<0.05)$ between total carbon stocks.

biomass and root carbon accumulated in the soil can be estimated from the aboveground biomass and compared with the changes in SOC over the same period. Using an average root: shoot ratio of $0.77: 1$ in the three species (Chen and Nie, 1978; Cheng et al., 2004; Fan et al., 2015; Sun et al., 2001), the $91 \mathrm{tha}^{-1}$ of aboveground biomass $\left(43 \mathrm{Mg} \mathrm{Cha}^{-1}\right)$ produced over the 7-year life of the alfalfa pasture would result in the production of $70 \mathrm{tha}^{-1}$ of root biomass or $33 \mathrm{MgCha}^{-1}$ of root carbon, significantly higher than the measured increase in SOC stock in the upper $2 \mathrm{~m}$ of the soil of $24 \mathrm{Mg} \mathrm{Cha}{ }^{-1}$. Similarly, using an aboveground biomass of $56 \mathrm{tha}^{-1}$, the estimated production of root biomass by milk vetch would be $43 \mathrm{tha}^{-1}$ and the estimated root carbon would be $20 \mathrm{MgCha}^{-1}$, also higher than the increase of $15 \mathrm{MgC} \mathrm{ha}^{-1}$ in SOC stock measured under milk vetch. However, using the same root: shoot ratio of $0.77: 1$, the aboveground biomass of bush clover of $42 \mathrm{tha}^{-1}$ would produce an estimated root biomass of $32 \mathrm{tha}^{-1}$ and a production of root carbon of $15 \mathrm{Mg} \mathrm{Cha}^{-1}$, compared with the measured SOC of $20 \mathrm{MgC} \mathrm{ha}^{-1}$. Thus the actual accumulation of SOC was about $70 \%$ of that estimated from the aboveground biomass in alfalfa and milk vetch, but was $33 \%$ higher than that estimated in bush clover. The difference between the estimated root carbon accumulated and the measured SOC stock under alfalfa and milk vetch over the 7-year period was presumably the result of losses by respiration by the roots and associated soil microbial populations. The observation that the measured values of SOC were higher than the root carbon production estimated from aboveground biomass may indicate that the root:shoot ratio was greater than $0.77: 1$ in bush clover (a root: shoot ratio of $1: 1$ would make the estimated and measured values the same), or the bush clover had a greater proportion and turnover of fine roots than milk vetch and alfalfa, resulting in a greater ac- 
cumulation of SOC (Shahzad et al., 2015). This is consistent with Sun et al. (2001) who reported that the fine roots (root diameter $<0.5 \mathrm{~mm}$ ) of bush clover accounted for $42 \%$ of total root biomass in $0-0.3 \mathrm{~m}$ soil layer, while the fine roots of milk vetch were only $25 \%$ of total root biomass (Chen and Nie, 1978).

The accumulation of SOC by bush clover was particularly high in the upper $0.3 \mathrm{~m}$ of the soil (Figs. 2 and 3). This accumulation of SOC in the upper soil layer may be attributable to the high accumulation of legume residues and litter (Zhou et al., 2006), or due to the proliferation and turnover of roots in this surface layer. Nevertheless, the sequestration of SOC in the upper $0.3 \mathrm{~m}$ of the soil in this study was significantly lower than Zhang et al. (2009) who reported that the SOC stocks in the upper $0.3 \mathrm{~m}$ of the soil increased by $16 \mathrm{MgC} \mathrm{ha}^{-1}$ in 10 years from the conversion of a wet reed meadow to an irrigated alfalfa pasture in the Hexi Corridor of northwest China. This suggests that well-managed legume pastures in areas with higher precipitation and with appropriate fertilizer use could sequester significantly more SOC than in the present unirrigated and unfertilized legumes growing in a semiarid environment.

An unexpected result from this study was the greater increase in SOC at soil depths from 1-2 $\mathrm{m}$ than above $1 \mathrm{~m}$, accounting for 79,68 and $74 \%$ of SOC sequestered through the whole $2 \mathrm{~m}$ of soil under alfalfa, bush clover and milk vetch, respectively. This suggests the presence of roots deep in the soil profile. Indeed, alfalfa and milk vetch have taproots that can penetrate to 6.8 and $7.6 \mathrm{~m}$, respectively, in loess soils in 6 years (Cheng et al., 2004, 2005), and the water extraction patterns measured on the plots used in this study clearly showed the presence of roots throughout the upper $2 \mathrm{~m}$ of the soil profile (Guan et al., 2013). In bush clover in which the proportion of SOC below $1 \mathrm{~m}$ was smaller than in the other two species, the taproot predominates in the $0-0.3 \mathrm{~m}$ soil layer with coarse roots (root diameter $>2 \mathrm{~mm}$ ) accounting for $48 \%$ of the total root biomass, and fine roots predominating below $0.3 \mathrm{~m}$ (Cheng et al., 2004, 2005; Sun et al., 2001). Although alfalfa extracted more water below $1 \mathrm{~m}$ than the other two species, the water extraction patterns do not suggest a greater root presence below $1 \mathrm{~m}$ in milk vetch than bush clover (Guan et al., 2013). We suggest that the greater increase in SOC at depth may be associated with a greater proliferation and turnover of fine roots at depth, or alternatively may reflect the movement down the profile of soluble $\mathrm{C}$ compounds from the roots as a result of the movement of water after heavy rainfall events.

The conversion of arable land that had been growing crops for many years to perennial legume pasture resulted in a significant increase in SOC, particularly at soil depths below $1 \mathrm{~m}$. All three legume species increased the SOC in the top $2 \mathrm{~m}$ of the soil profile, but the increase was greatest in alfalfa and least in milk vetch. While the production of aboveground biomass was least in bush clover, the SOC sequestration in the soil profile was not significantly different from alfalfa, indicating that carbon sequestration in the soil is not simply associated with aboveground biomass production in a system in which the forage is removed for animal feed, as in the present study. Further study of root biomass production, turnover of fine roots and exudation of carboxylic acids and other carbon compounds by the roots of the legume species would be a valuable step in understanding the differences in carbon sequestration by the three species.

Acknowledgements. This research was supported by grants (no. 31470496 and no. 31471452) from the National Natural Science Foundation of China, the National Key Technology R\&D Program of China (Projects 2012BAD04B07 and 2012BAD14B08) and the Innovation Team Program of the Ministry of Education of China (no. IRT_13R26). This research was also supported by the Fundamental Research Funds for the Central Universities (lzujbky-2015-ct02), and the Program of Introducing Talents of Discipline to Universities ("111 Project 2007B051"). We are grateful to Xiao-Hong Zhang for her help in the laboratory. NCT thanks the Centre for Plant Genetics and Breeding and the UWA Institute of Agriculture at the University of Western Australia for financial support. This work is a part of the doctoral dissertation of the first author, Xiao-Kang Guan, at Lanzhou University.

Edited by: S. Fontaine

\section{References}

Chen, B. and Nie, C.: Research of Astragalus adsurgens Pall. root system, Journal of Gansu Agricultural University, 2, 71-75, 1978 (in Chinese with English abstract).

Chen, H., Shao, M., and Li, Y.: Soil desiccation in the Loess Plateau of China, Geoderma, 143, 91-100, 2008.

Cheng, J., Wan, H. E., and Wang, J.: Alfalfa growth and its relation with soil water status in loess hilly and gully region, J. Appl. Ecol., 16, 435-438, 2005 (in Chinese with English abstract).

Cheng, J. M., Wan, H. E., Wang, J., and Yong, S. P.: Over depletion and recovery of soil moisture on Astragalus adsurgens grasslands in the loess hilly-gully region, Acta Ecologica Sinica, 24, 29792983, 2004 (in Chinese with English abstract).

Fan, J. W., Du, Y. L., Turner, N. C., Wang, B. R., Fang, Y., Xi, Y., Guo, X. R., and Li, F. M.: Changes in root morphology and physiology to limited phosphorus and moisture in a locally-selected cultivar and an introduced cultivar of Medicago sativa L. growing in alkaline soil, Plant Soil, 392, 215-226, 2015.

Fu, X., Shao, M., Wei, X., and Horton, R.: Soil organic carbon and total nitrogen as affected by vegetation types in Northern Loess Plateau of China, Geoderma, 155, 31-35, 2010.

Gentile, R. M., Martino, D. L., and Entz, M. H.: Influence of perennial forages on subsoil organic carbon in a long-term rotation study in Uruguay, Agriculture, Ecosys. Environ., 105, 419-423, 2005.

Guan, X. K., Zhang, X. H., Turner, N. C., Xu, B. C., and Li, F. M.: Two perennial legumes (Astragalus adsurgens Pall. and Lespedeza davurica $\mathrm{S}$.) adapted to semiarid environments are not as productive as lucerne (Medicago sativa L.), but use less water, Grass Forage Sci., 68, 469-478, 2013. 
He, Z., Huang, C., Zheng, H., Zhou, J., Pang, J., Li, X., and Wang, L.: Holocene loess and its deposition dynamics in the upper reaches of the Huaihe River, J. Geogr. Sci., 21, 561-573, 2011.

IPCC: Land-use, land-use change, and forestry, in: Land use, landuse change, and forestry: a special report of the intergovernmental panel on climate change, edited by: Watson, R. T., Noble, I. R., Bolin, B. R., Ravindranath, N. H., Verardo, D. J., and Dokken, D. J., Cambridge University Press, UK, 2000.

Lal, R.: Soil carbon dynamics in cropland and rangeland, Environ. Pollut., 116, 353-362, 2002.

Lal, R.: Offsetting China's $\mathrm{CO}_{2}$ Emissions by Soil Carbon Sequestration, Climatic Change, 65, 263-275, 2004a.

Lal, R.: Soil carbon sequestration impacts on global climate change and food security, Science, 304, 1623-1627, $2004 \mathrm{~b}$.

Lal, R.: Soil carbon sequestration to mitigate climate change, Geoderma, 123, 1-22, 2004c.

Luo, Y., Meyerhoff, P. A., and Loomis, R. S.: Seasonal patterns and vertical distributions of fine roots of alfalfa (Medicago sativa L.), Field Crops Res., 40, 119-127, 1995.

Mangnussen, S. and Reed, D.: Modeling for Estimation and Monitoring, available at: http://www.fao.org/fileadmin/user_ upload/national_forest_assessment/images/PDFs/English/KR2_ EN_10.pdf, 2004.

Moinuddin, K.-C. and Khanna-Chopra, R.: Osmotic Adjustment in Chickpea in Relation to Seed Yield and Yield Parameters, Crop Sci., 44, 449-455, 2004.

Munson, S., Lauenroth, W., and Burke, I.: Soil carbon and nitrogen recovery on semiarid Conservation Reserve Program lands, J. Arid Environ., 79, 25-31, 2012.

Osborn, T.: The conservation reserve program: Status, future and policy options, J. Soil Water Conserv., 48, 271-279, 1993.

Puget, P. and Lal, R.: Soil organic carbon and nitrogen in a Mollisol in central Ohio as affected by tillage and land use, Soil Till. Res., 80, 201-213, 2005.

Shahzad, T., Chenu, C., Genet, P., Barot, S., Perveen, N., Mougin, C., and Fontaine, S.: Contribution of exudates, arbuscular mycorrhizal fungi and litter depositions to the rhizosphere priming effect induced by grassland species, Soil Biol. Biochem., 80, 146$155,2015$.

Smith, P.: Land use change and soil organic carbon dynamics, Nutr. Cycl. Agroecosys., 81, 169-178, 2008.

Smith, P., House, J. I., Bustamante, M., Sobocká, J., Harper, R., Pan, G., West, P., Clark, J., Adhya, T., Rumpel, C., Paustian, K., Kuikman, P., Cotrufo, M. F., Elliott, J. A., McDowell, R., Griffiths, R. I., Asakawa, S., Bondeau, A., Jain, A. K., Meersmans, J., and Pugh, T. A. M.: Global Change Pressures on Soils from Land Use and Management, Glob. Change Biol., 1-21, doi:10.1111/gcb.13068, 2015.
Staben, M., Bezdicek, D., Fauci, M., and Smith, J.: Assessment of soil quality in conservation reserve program and wheat-fallow soils, Soil Sci. Soc. Am. J., 61, 124-130, 1997.

Sun, Q., Han, J., Gui, R., Li, Z., and Liu, G.: Biomass in Lespedeza dahurica S., Grassland of China, 4, 21-26, 2001 (in Chinese with English abstract).

Wang, G.: Differences in leaf $\delta 13 \mathrm{C}$ among four dominant species in a secondary succession sere on the Loess Plateau of China, Photosynthetica, 41, 525-531, 2003.

Wang, Y., Shao, M. A., and Shao, H.: A preliminary investigation of the dynamic characteristics of dried soil layers on the Loess Plateau of China, J. Hydrol., 381, 9-17, 2010.

Wang, Y., Fu, B., Lü, Y., and Chen, L.: Effects of vegetation restoration on soil organic carbon sequestration at multiple scales in semi-arid Loess Plateau, China, Catena, 85, 58-66, 2011.

$\mathrm{Wu}, \mathrm{J}$. and Lin, H.: The effect of the conservation reserve program on land values, Land Economics, 86, 1-21, 2010.

Xu, B., Gichuki, P., Shan, L., and Li, F.: Aboveground biomass production and soil water dynamics of four leguminous forages in semiarid region, northwest China, South African Journal of Botany, 72, 507-516, 2006.

Yan, H., Cao, M., Liu, J., and Tao, B.: Potential and sustainability for carbon sequestration with improved soil management in agricultural soils of China, Agriculture, Ecosys. Environ., 121, 325-335, 2007.

Zhang, C., Liu, G., Xue, S., and Sun, C.: Soil organic carbon and total nitrogen storage as affected by land use in a small watershed of the Loess Plateau, China, Eur. J. Soil Biol., 54, 16-24, 2013.

Zhang, T., Wang, Y., Wang, X., Wang, Q., and Han, J.: Organic carbon and nitrogen stocks in reed meadow soils converted to alfalfa fields, Soil Till. Res., 105, 143-148, 2009.

Zhou, Z., Sun, O. J., Huang, J., Li, L., Liu, P., and Han, X.: Soil carbon and nitrogen stores and storage potential as affected by land-use in an agro-pastoral ecotone of northern China, Biogeochemistry, 82, 127-138, 2006.

Zhu, X.: The formation and significance of loess-soil struction profile, J. Soil Water Conserv., 8, 1-9, 1994 (in Chinese with English abstract). 